\title{
The Relationship between Private Domain and Commercial Domain of Hospitality in Airlines: Employing Partial Least Square Technique
}

\author{
Ehsaneh N. M. Nameghi ${ }^{1}$ \\ ${ }^{1}$ Graduate School of Business, National University of Malaysia, Bangi, Malaysia \\ Correspondence: Ehsaneh N. M. Nameghi, Graduate School of Business, National University of Malaysia, Bangi, \\ Malaysia. E-mail: ehsaneh_nameghi@yahoo.com
}

Received: November 20, 2012 Accepted: December 14, 2012 Online Published: February 28, 2013

doi:10.5539/ijms.v5n2p102 URL: http://dx.doi.org/10.5539/ijms.v5n2p102

\begin{abstract}
The purpose of the present study is to understand the relationship between passengers' level of hospitality performance in private setting and their expectation of hospitality provision in airlines as commercial setting. The present study sample consists of 546 passengers. The Partial Least Square Technique (PLS) was applied as the research method. Finding indicates that there is positive relationship between commercial hospitality dimensions and private domain of hospitality in an airline context. Present study can be considered as the pioneer on confirming private and commercial hospitality relationship in an airline context. Understanding relationship among commercial and private domain of hospitality will help airline managers to apply better strategies for attracting more passengers.
\end{abstract}

Keywords: private domain, commercial domain, airline hospitality, passengers

\section{Introduction}

Private domain of hospitality refers to practice and image each individual have regarding hospitality while commercial hospitality is application of hospitality in commercial setting (Lashley, 2008). Airline industry as an important service industry plays a significant role on tourism mobility. In fact airlines quality of treatment manner as well as hospitality provided can provide memorable and joyful experience for passengers. Present study looks at the emergence of hospitality in airline industry and its relationship with private domain of hospitality.

\section{Literature Review}

\subsection{Commercial Domain of Hospitalithy}

Researchers try to find a proper answer for the following questions: can hospitality be considred as a discrete entity; is hospitality generic or contextually contingent? and is possible to introduce a framework for hospitality that can be operationalized in the real world? (Brotherton 2006). Different researchers have tried to come up with a proper theory for hospitality, while their approaches in order to define hospitality theory were different. For example, Brotherton (2006) has tried to find whether hospitality is an entity independent from other majors or may have some overlapping with other discipline such as tourism, leisure and traveling by using a general system theory. His finding shows that hospitality can be considered as an independent discipline, although its relationships with other majors mentioned are undeniable. His proposed model contains some parameters that comprise independent variables, such as economic, socio-cultural, political-legal and technological variables, combined with intervening variables (commercial hospitality and hospitality behavior).

Jones (2004) has come up with five schools of thoughts for hospitality namely: (1)hospitality science model: which is more on physical and natural science and use the theories and research models of , biology, chemistry, physics. The research types would be more on ergonomics, diet and equipment performance, (2) hospitality management school: refers to a positivist, empirical and quantitative approach, which studies like hospitality marketing and consuming can be defined under this category, (3) hospitality studies: which is bases is more on philosophy of science rather than a positivist approach, while it contains both qualitative and quantitative research methodology, (4) Hospitality systems: is based on the positivist and normative research, and it uses a wide range of the methodologies while mostly is based on overarching philosophy. A limited number of Canadian and UK philosophers have contributed to this school of thought and (5) hospitality relationship: 
Lashley (2000) "three-dimensional definition of hospitality" can be considered as a leader of this school of thought. He defines hospitality as an individual concept from other concepts such as management and defines it as a social, private and commercial hospitality. Social hospitality refers to cultural and religious obligations and customs in host-guest relationship. Private domain of hospitality refers to practice and image each individual have regarding hospitality and commercial hospitality is application of hospitality in commercial setting.

Hospitality as reciprocity between host and guest (Lashley 2008), presents communication between host and guest whether in private or commercial domain of hospitality. Communication in private domain refers to host buys a gift or guest buying a gift. The host is providing the best things for its guest in order to provide a memorable stay for him. Communication in a commercial hospitality domain refers to suprising kids by gifts, personal safety and caring of the guests like helping them to find the address of their hotels (Talbott 2006). In other word, communication has been considered as strong emotional connections within host and guest when a personal service is given or received (Talbott 2006).

Lashley (2008) conducts five principles for hospitality: (1) the guest and host relationship should be "natural", (2) a vital element of being a host is having regard for the holy nature of the guest (which is about the honour and position to which a guest side may convey to the host), (3) hospitality ought to be noble, (4) altruistic and generosity behavior can be considered as crucial segment in English social life, (5) hospitality exchange as well as social interactions is as significant as those interactions shaped in the commercial settings (Heal 1990).

Based on Lashley (2008), hospitality is meeting the physiological and psychological needs of the guests. In other word, hospitality should be defined as an emotional and functional reciprocity between host and guest. Host should have the potential to provide a memorable experience and good feeling for its guest following by a good memory of service offering for its guests as well. Different researchers have focused on the concept of hospitality based on emotional and functional dimension, although they do not highlight that. Morrison and O'Gorman (2008) have defined the principles of hospitality as follows: guests is always welcome, service should be offered at different levels, hospitality is performed according to the guests necessities, specific hospitality performance is required for guests who have special needs, hospitality provision must consist of basic needs such as (food, drink and accommodation) as well as other needs. In addition availability of food and drink for guests must be all the time they arrive.

Welcoming following by an attempt to fulfill and offer good services refers to provision of pleasure stay for the guests in order to make available a memorable stay for guests. Indeed, this is nothing more than fulfillment of emotional needs of guests and dealing with psychological aspects in hospitality. Emotional aspect in hospitality can also be referred to qualities (Lashley 2008). For example, desire to please others and friendliness and benevolence followed by concerning about others and compassion and providing entertain for guest. On the other hand the desire to meet guest's need based on a functional aspect in hospitality (such as provision of food, drink and accommodation and availability of service), refers to answer physical needs of guests.

Hepple, Kipps and Thomson (1990) define hospitality based on four characteristics, firstly. Hospitality is a reciprocity behavior between host and guest, second it contains interactive contact between service provider and receiver, thirdly hospitality is a mixture of tangible and intangible factors and finally; host tries to fulfill the psychological and physiological factors such as security and comfort.

Hospitability is a true emotional experience and should be inherited emotionally. It should come from the heart, while being open and warm to others and have a potential to abandon and suspend the rational judgment from itself. This is derived from private domain of hospitality, which is based on the old concept of hospitality that the host will accept the guest in its home with warm welcome, pleasure and true smile. The story would be different in the commercial hospitality because, the host should have the potential of performing good behavior and manner of hospitality. Indeed, the concern in commercial domain is that the guest would feel sincerely in host smile and perceive it as natural hospitality or not.

Hospitality should be available in different service industries while the level of guests' hospitality expectation in commercial hospitality domain is highly dependent on service providers category. This means that guests have higher expectation from tourism and leisure oriented service providers (such as hotels, motels or even transportation industry such as airlines) rather than other service providers (such as banks or hospitals). Tourists and passengers expect pleasure and memorable experience from tourism related services. Hence, the present study major objective is to understand private hospitality as conceptual background of commercial hospitality applied in the airline industry. 


\subsection{Private Domain of Hospitality}

Beerli et al., (2007) state that James is one of the self-identity theory founders, and in 1890 , he define self-identity as the "total sum of what a man thinks of himself, including his body and intellect, as well as his belongings, family, reputation, and work." Consumers in general tend to choose products or brand that match up to their self-concept. This means that consumer or service receiver try to choose products or services, which has most commonality with his/her character. The greater the congruence, the greater to purchase product or service (Landon, 1974 cited in Yuksel \& Riley, 2003).

Studies have investigated self-congruity theory and its impact on tourist destinations, and this research found that both ideal congruity and actual congruity have a positive effect on behavioural intentions (Usakli \& Baloglu, 2011). The greater the harmony and congruity that exists among a destination's image and individuals self-concept, the greater the tourist's intention to visit that destination (Beerli et al., 2007).

In the present study, self-image is conceptualized as the consistency and congruence between personal levels of hospitableness and the hospitality provided at the airline. Self-image from a hospitality perspective can also be investigated using private hospitality, which is based on the fact that each person practices a different type or level of hospitableness based on religion, national customs, personal characteristics, etc. (O'Connor, 2005). O'Connor (2005) argues that there is a general connection of hospitality with the word "natural." This means that in every individual has a different variety and level of natural hospitality. Those who have a higher degree of natural hospitality, behave more hospitable.

Based on above mentioned statement, we can argue that the person, who practices higher level of natural hospitality, cares more about hospitality and treatment. Based on the definition of hospitality, a reciprocal relationship is expected, and a person may expect the same level of hospitality from others when she is their guest. Therefore, a person who practices a higher level of natural hospitality cares more about hospitality and treatment.

Ariffin and Maghzi (2012) explain that private hospitality is concerned with the host's hospitality toward others in a private setting, such as a home. This domain is crucial because it is the point of reference people normally use to assess the hospitality level in commercial settings.

The more hospitable the person is toward the guest, the same level of hospitality performance he/she may expect from others in the private domain hospitality. Of course, this can be applicable to commercial hospitality as well. This means that when a person cares and pays attention to hospitality provision, he expects that a service provider perform the same level of natural hospitality in return. O'Connor (2005) mentions that one quality or skill a person is born with is the capability, in varying degrees, to evaluate if one's host is being authentically hospitable. Therefore it is postulated:

H1: There is a positive relationship between the self-image (private hospitality) and airline passengers' hospitality expectations.

\section{Methodology}

\subsection{Data Collection}

A structured questionnaire was distributed among air travellers at the Kuala Lumpur International Airport (KLIA), and 546 questionnaires were completed. All the scales employed in this study were adopted from established measurements. Partial least squares (PLS) was the main statistical method used to test the hypothesis. The sample consists of $52.9 \%$ male, and $47.1 \%$ female. The majority of the respondents $(39.2 \%)$ fall in the age range of 20 to $<30$ years old. With respect to academic qualifications, a majority (45.6\%) of the respondents had received a bachelor's degree while $19 \%$ of the respondents had obtained their postgraduate degrees. $56.0 \%$ were employed while $17.6 \%$ of respondents were students. The majority of the respondents were Malaysians (76.7\%) and $23.3 \%$ were non-Malaysians. Most of the respondents' (41.4\%) main purpose of travel was for leisure. The reliability test is present in Table1.

Table 1. Reliability test

\begin{tabular}{lllll}
\hline Variables & Mean & $\begin{array}{l}\text { Standard } \\
\text { Deviation }\end{array}$ & No. of Items & $\begin{array}{l}\text { Cronbach's } \\
\text { Alpha }\end{array}$ \\
\hline $\begin{array}{l}\text { Airline Hospitality } \\
\begin{array}{l}\text { Self-Image } \\
\text { (Private Hospitality) }\end{array}\end{array}$ & 4.56 & .885 & 22 & 0.96 \\
\hline
\end{tabular}




\subsection{Measurement Items}

Self-Image is operationally defined as passengers overall belief or perception toward their own hospitableness in the private setting (adapted from Yuksel \& Riley 2003; O'Connor 2005). For this study, self-image hospitality is measured using five items borrowed from Ariffin and Maghzi (2012). The items used to measure self-image are shown in Table 2 . They are measured on 6-point scales from 1 (strongly disagree) to 6 (strongly agree).

Table 2. Measurement for self-image (private hospitality)

\begin{tabular}{|c|c|c|c|}
\hline Construct & Items & Main Source(s) & $\begin{array}{l}\text { Cronbach's } \\
\text { Alpha }\end{array}$ \\
\hline $\begin{array}{l}\text { Self-Image } \\
\text { (Private Hospitality) }\end{array}$ & $\begin{array}{l}\text { 1- I love to entertain my family and } \\
\text { friends for dinner/lunch } \\
\text { 2- I make sure that all the people that } \\
\text { come to my house (for any purpose) } \\
\text { would be offered at least a drink } \\
\text { 3-I would be happy to accommodate other } \\
\text { people when I come to my town } \\
\text { 4- I usually give something as a token/gift } \\
\text { to my guests to take home } \\
\text { 5- I would offer my guest the best room in } \\
\text { the house for their utmost comfort }\end{array}$ & $\begin{array}{l}\text { Ariffin \& Maghzi } \\
(2012)\end{array}$ & 0.84 \\
\hline
\end{tabular}

This present study investigates hospitality hosting behavior in the context of airline industry. The hospitality items were adopt and adapted from the following sources:Wilkins, Merrilees, Herington (2007); Mohsin \& Lockyer (2010); Wu \& Liang (2009); Meng \&Elliott (2008), Hyun, Kim, Lee (2011); Chen(2008); Kim \&Moon (2009); Pakdil \& Aydın (2007); Gilbert \& Wong (2003); Dubé and Renaghan (1999); Heung, Wong and Qu (2000); Barsky \& Nash (2002), Forgas, Moliner, Sa'nchez, Palau (2010); O’Connell \&Williams(2005); Liu \& Jang (2009).

\subsection{Construct Validity}

The construct validity refers to the degree to which the model employed in the study fits the theories being tested (Sekaran and Bougie, 2010).For construct validity, the loading and cross-loading of the items were investigated. Significant loading is 0.5 and above (Hair et al., 2010). Table 3 shows that all the items representing one construct are loaded highly on that construct while the other constructs are loaded much lower. Therefore, present study has construct validity.

Table 3. Loading and cross loading

\begin{tabular}{llllll}
\hline & Appreciation & Comfort & Courtesy & PHOS & Socializing \\
\hline AIRHOS27 & $\mathbf{0 . 8 4 4 9}$ & 0.457 & 0.4549 & 0.4583 & 0.3595 \\
AIRHOS28 & $\mathbf{0 . 8 8 6 4}$ & 0.4668 & 0.3208 & 0.3755 & 0.4555 \\
AIRHOS30 & $\mathbf{0 . 6 6 2 8}$ & 0.2516 & 0.5 & 0.324 & 0.3339 \\
AIRHOS8 & $\mathbf{0 . 8 5 8 6}$ & 0.2867 & 0.3946 & 0.4992 & 0.3971 \\
AIRHOS9 & $\mathbf{0 . 8 4 7}$ & 0.3358 & 0.3719 & 0.4962 & 0.2918 \\
AIRHOS18 & 0.6873 & $\mathbf{0 . 8 3 6 9}$ & 0.6729 & 0.4089 & 0.6625 \\
AIRHOS19 & 0.5836 & $\mathbf{0 . 8 1 9 1}$ & 0.6002 & 0.3354 & 0.6637 \\
AIRHOS21 & 0.6511 & $\mathbf{0 . 8 5 8 5}$ & 0.6534 & 0.412 & 0.6848 \\
AIRHOS22 & 0.6787 & $\mathbf{0 . 8 6 2 4}$ & 0.6852 & 0.4479 & 0.5836 \\
AIRHOS23 & 0.6689 & $\mathbf{0 . 8 5 8}$ & 0.7038 & 0.409 & 0.5659 \\
AIRHOS1 & 0.3188 & 0.4533 & $\mathbf{0 . 8 6 1 4}$ & 0.4511 & 0.4808 \\
AIRHOS12 & 0.3106 & 0.4178 & $\mathbf{0 . 8 1 7 8}$ & 0.4656 & 0.0852 \\
AIRHOS2 & 0.1392 & 0.2826 & $\mathbf{0 . 8 9 9 5}$ & 0.4636 & 0.4358 \\
AIRHOS3 & 0.4536 & 0.4062 & $\mathbf{0 . 9 0 9 3}$ & 0.3071 & 0.2979 \\
AIRHOS4 & 0.3756 & 0.1083 & $\mathbf{0 . 9 1 4 4}$ & 0.2223 & 0.2122 \\
AIRHOS5 & 0.363 & 0.4865 & $\mathbf{0 . 8 6 7 2}$ & 0.2579 & 0.3708 \\
PHOSa & 0.4776 & 0.4068 & 0.4573 & $\mathbf{0 . 8 3 2 5}$ & 0.3402 \\
\hline
\end{tabular}




\begin{tabular}{llllll}
\hline PHOSb & 0.406 & 0.4275 & 0.4147 & $\mathbf{0 . 8 5 9 8}$ & 0.3113 \\
PHOSc & 0.4919 & 0.439 & 0.4161 & $\mathbf{0 . 8 8 7 6}$ & 0.3867 \\
PHOSd & 0.3073 & 0.2984 & 0.3041 & $\mathbf{0 . 6 8 8 1}$ & 0.4038 \\
PHOSe & 0.4571 & 0.3622 & 0.4079 & $\mathbf{0 . 8 1 1}$ & 0.3863 \\
AIRHOS6 & 0.2287 & 0.4911 & 0.3377 & 0.355 & $\mathbf{0 . 8 1 3}$ \\
AIRHOS7 & 0.4851 & 0.4582 & 0.4969 & 0.3256 & $\mathbf{0 . 8 0 5 3}$ \\
AIRHOS13 & 0.4438 & 0.4127 & 0.3617 & 0.3732 & $\mathbf{0 . 7 9 4 1}$ \\
AIRHOS14 & 0.2497 & 0.3089 & 0.212 & 0.1695 & $\mathbf{0 . 5 0 0 2}$ \\
AIRHOS15 & 0.4683 & 0.3469 & 0.4584 & 0.3837 & $\mathbf{0 . 8 0 4}$ \\
AIRHOS6 & 0.3287 & 0.4911 & 0.3377 & 0.355 & $\mathbf{0 . 8 1 3}$ \\
\hline
\end{tabular}

Note: The bold values represents items which loaded above the threshold value (0.5).

\subsection{Convergent Validity}

Composite reliability, average variance extracted as well as factor loading can be used to measure convergent validity (Hair et al. 2010). As shown in Table 4, composite reliability exceeds the Hair (2010) recommended cut off point of 0.7. The average variance extracted (AVE) exceeds the recommended value of 0.5 (Barclay et al. 1995). The (AVE) in present study were in the range of 0.5673 and 0.7725 . The measurement model (Table 5) indicates that airline hospitality and self-image (private hospitality) are valid based on parameter estimates and statistical significance.

Table 4. Measurement model

\begin{tabular}{|c|c|c|c|c|c|c|}
\hline Constructs & & $\begin{array}{l}\text { Measurement Items } \\
\text { Loading }\end{array}$ & & AVE & $\begin{array}{l}\text { Composite } \\
\text { Reliability }\end{array}$ & $\begin{array}{l}\text { Cronbachs } \\
\text { Alpha }\end{array}$ \\
\hline \multirow{22}{*}{$\begin{array}{l}\text { Airline } \\
\text { Commercial } \\
\text { Hospitality }\end{array}$} & \multirow{5}{*}{ Appreciation } & 1.AIRHOS8 & 0.858 & & & \\
\hline & & 2.AIRHOS9 & 0.847 & 0.6787 & 0.9128 & 0.8796 \\
\hline & & 3.AIRHOS27 & 0.844 & & & \\
\hline & & 4.AIRHOS28 & 0.886 & & & \\
\hline & & 5.AIRHOS30 & 0.662 & & & \\
\hline & \multirow{6}{*}{ Comfort } & 1.AIRHOS18 & 0.836 & & & \\
\hline & & 2.AIRHOS19 & 0.819 & 0.698 & 0.9326 & 0.9133 \\
\hline & & 3.AIRHOS21 & 0.858 & & & \\
\hline & & 4.AIRHOS22 & 0.862 & & & \\
\hline & & 5.AIRHOS23 & 0.858 & & & \\
\hline & & 6.AIRHOS25 & 0.774 & & & \\
\hline & \multirow{6}{*}{ Courtesy } & 1.AIRHOS1 & 0.861 & & & \\
\hline & & 2.AIRHOS2 & 0.899 & 0.7725 & 0.9531 & 0.9408 \\
\hline & & 3.AIRHOS3 & 0.909 & & & \\
\hline & & 4.AIRHOS4 & 0.914 & & & \\
\hline & & 5.AIRHOS5 & 0.867 & & & \\
\hline & & 6.AIRHOS12 & 0.817 & & & \\
\hline & \multirow{5}{*}{ Socializing } & 1.AIRHOS6 & 0.813 & & & \\
\hline & & 2.AIRHOS7 & 0.805 & 0.5673 & 0.8646 & 0.8046 \\
\hline & & 3.AIRHOS13 & 0.794 & & & \\
\hline & & 4.AIRHOS14 & 0.500 & & & \\
\hline & & 5.AIRHOS15 & 0.804 & & & \\
\hline \multirow{5}{*}{$\begin{array}{l}\text { Private } \\
\text { Hospitality }\end{array}$} & \multirow{5}{*}{ PHOS } & PHOSa & 0.832 & & & \\
\hline & & PHOSb & 0.859 & 0.6703 & 0.9099 & 0.8753 \\
\hline & & PHOSc & 0.887 & & & \\
\hline & & PHOSd & 0.688 & & & \\
\hline & & PHOSe & 0.811 & & & \\
\hline
\end{tabular}


Table 5. Model summary results

\begin{tabular}{|c|c|c|c|c|}
\hline Constructs & & Measurement Items & Loading & T-Value \\
\hline \multirow{22}{*}{$\begin{array}{l}\text { Airline } \\
\text { Commercial } \\
\text { Hospitality }\end{array}$} & \multirow{5}{*}{ Appreciation } & 1.AIRHOS8 & 0.858 & 52.3847 \\
\hline & & 2.AIRHOS9 & 0.847 & 51.1684 \\
\hline & & 3.AIRHOS27 & 0.844 & 44.6672 \\
\hline & & 4.AIRHOS28 & 0.886 & 72.7294 \\
\hline & & 5.AIRHOS30 & 0.662 & 14.8302 \\
\hline & \multirow{6}{*}{ Comfort } & 1.AIRHOS18 & 0.836 & 46.3795 \\
\hline & & 2.AIRHOS19 & 0.819 & 41.2431 \\
\hline & & 3.AIRHOS21 & 0.858 & 52.8674 \\
\hline & & 4.AIRHOS22 & 0.862 & 72.4267 \\
\hline & & 5.AIRHOS23 & 0.858 & 72.1519 \\
\hline & & 6.AIRHOS25 & 0.774 & 31.9531 \\
\hline & \multirow{6}{*}{ Courtesy } & 1.AIRHOS1 & 0.861 & 51.3004 \\
\hline & & 2.AIRHOS2 & 0.899 & 87.0149 \\
\hline & & 3.AIRHOS3 & 0.909 & 76.8661 \\
\hline & & 4.AIRHOS4 & 0.914 & 94.1508 \\
\hline & & 5.AIRHOS5 & 0.867 & 51.7084 \\
\hline & & 6.AIRHOS12 & 0.817 & 35.6379 \\
\hline & \multirow{5}{*}{ Socializing } & 1.AIRHOS6 & 0.813 & 40.4519 \\
\hline & & 2.AIRHOS7 & 0.805 & 36.8892 \\
\hline & & 3.AIRHOS13 & 0.794 & 28.5327 \\
\hline & & 4.AIRHOS14 & 0.500 & 3.6728 \\
\hline & & 5.AIRHOS15 & 0.804 & 37.2473 \\
\hline \multirow{5}{*}{$\begin{array}{l}\text { Private } \\
\text { Hospitality }\end{array}$} & \multirow{5}{*}{ PHOS } & PHOSa & 0.832 & 48.2307 \\
\hline & & PHOSb & 0.859 & 51.4541 \\
\hline & & PHOSc & 0.887 & 76.845 \\
\hline & & PHOSd & 0.688 & 24.3663 \\
\hline & & PHOSe & 0.811 & 37.9831 \\
\hline
\end{tabular}

\subsection{Discriminant Validity}

Correlational analysis among the construct measurements was employed in order to assess discriminant validity .Compeau et al. (1999) states that the items should be loaded higher in the construct in which they belong. Correlations among the constructs are presented in Table 6. Constructs correlation are less that (AVE) of each construct; therefore, discriminant validity exists among the constructs in the present study.

Table 6. Discriminant validity

\begin{tabular}{llllll}
\hline Constructs & 1 & 2 & 3 & 4 & 5 \\
\hline 1. Appreciation & 0.8238 & & & & \\
2. Comfort & 0.7772 & 0.8354 & & & \\
3. Courtesy & 0.8163 & 0.7881 & 0.8789 & 0.8187 & \\
4. PHOS & 0.5536 & 0.4766 & 0.5451 & 0.4412 & 0.7531 \\
5. Socializing & 0.7131 & 0.7485 & 0.716 & \\
\hline
\end{tabular}

Note: the Diagonal is the square root of AVE

\subsection{Hypotheses Testing}

The hypotheses testing results are presented in Figure 1 and Table 7 . The $\mathrm{R}^{2}$ value for courtesy as airline hospitality dimension is 0.545 , which explains that $54.5 \%$ of the variance in courtesy dimension can be explained by self-image (private hospitality). Also the $\mathrm{R}^{2}$ value for other airline hospitality dimensions comfort; socializing and appreciation were $0.477,0.440,0.554$ respectively which indicates that private hospitality have $47.7 \%, 44 \%$ and $55.4 \%$ explanatory power on comfort, socialzing and appreciation.

Private hospitality is positively related $(b=0.183, \mathrm{p}<0.01)$ to the level of customer's airline courtesy, comfort 
$(b=0.150, p<0.01)$ expectations. In addition, self-image (private hospitality) has also a significant relationship $(b=0.394, p<0.01)$ with customers' airline socializing and appreciation expectations $(b=0.394, p<0.01)$. Thus, study hypothesis were supported.

Table 7. Hypotheses testing and path coefficients

\begin{tabular}{lllll}
\hline Hypothesis & Relationship & Coefficient & t-value & Supported \\
\hline & PHOS----> Courtesy & 0.545 & 14.0709 & \\
H1 PHOS----> Airhos & PHOS ----> Comfort & 0.477 & 11.8759 & \\
& PHOS ----> Socializing & 0.440 & 11.3791 & Supported \\
& PHOS ----> Appreciation & 0.554 & 14.3246 & \\
\hline
\end{tabular}

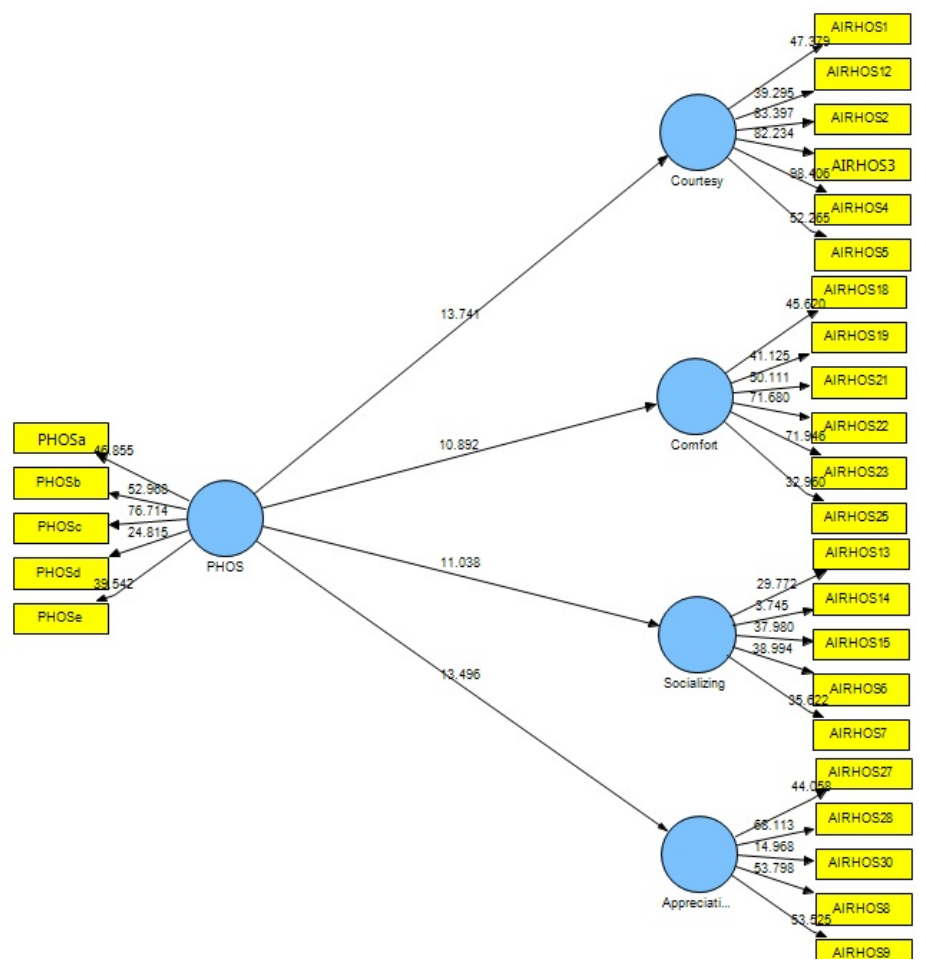

Figure 1. Path analysis

Present study was conducted among public and private universities students in Malaysia using a questionnaire. The reason to use university students as the sample is due to its homogeneity (Peterson, 2001) as well as its applicability in many environmental studies (Milfont and Duckitt 2010; Duerden and Witt 2010; Ramayah et al., 2012). The non probability sampling technique was used since a sampling frame was not available. A total of 315 usable responses employed to gather. The questionnaire consists of six sections to ask about all study variables. A 6-point "Liker" scale were used to measure responses from 1 representing strongly disagree and 6 representing strongly agree. The demographic questions were gathered in the final section of the questionnaire. The model was tested using Partial Least Square Technique (PLS) (Smart PLS version 2).

\section{Conclusions}

This present study empirically examines the relationship between commercial and private hospitality in an airline context. From the analysis presented, it is evident that private hospitality has positive significant effect on commercial hospitality. In other word, hospitable passengers have certain level of expectation from hospitality provided within the flights. The more hospitable the person is, the more would expect from airlines. In addition findings indicate that hospitable passengers expect more hospitable treatment manner from appreciation perspective followed by courtesy, comfort and socializing. This can be considered as a valuable guideline to understand what are the elements that passengers mostly consider as airline hospitality determinants. Appreciation refers to greeting (welcome and goodbye) manner, genuine invitation to fly again with airline. 
Courtesy as second important dimension explains the in-flight respect provided by the cabin crews such as (interaction with passengers in full respect, prompt service offering and personal attention to passengers needs). Passengers airlines comfort expectation which stands in third position is about facilities and services provided during flight. Passengers consider lower level for (gifts or token, entertainment, comfort kit such as pillow) and cabin crews socializing behavior (spending too much time with passengers or engaging small talk with them) in comparison with treatment manner, courtesy and appreciation.

\section{References}

Ariffin, A. A., \& Maghzi, A. (2012). A preliminary study on customer expectations of hotel hospitality: Influences of personal and hotel factors. International Journal of Hospitality Management, 31, 191-198. http://dx.doi.org/10.1016/j.ijhm.2011.04.012

Barclay, D. W., Thompson, R., \& Higgins, C. (1995). The partial least squares (PLS) approach to causal modeling: personal computer adoption and use an illustration. Technol Stud, 2(2), 285-309.

Barsky, J., \& Nash, L. (2002). Evoking Emotion: Affective Keys to Hotel Loyalty. Cornell Hotel and Restaurant Administration Quarterly, 43, 39. http://dx.doi.org/10.1016/S0010-8804(02)80007-6

Beerli, A., Dı'az Meneses, G., Moreno \& Gil, S. (2007). Self-congruity and destination choice. Annals of Tourism Research, 34(3), 571-587. http://dx.doi.org/10.1016/j.annals.2007.01.005

Brotherton, B. (2006). Some thoughts on a general theory of hospitality. Tourism today, Fall.

Chen, C. F. (2008). Investigating structural relationships between servicequality, perceived value, satisfaction, and behavioural intentions for air passengers: Evidence from Taiwan. Transportation Research, 42, 709-717.

Compeau, D. R., Higgins, C. A., \& Huff, S. (1999). Social cognitive theory and individual reactions to computing technology: a longitudinal-study. MISQ, 23(2), 145-158. http://dx.doi.org/10.2307/249749

Dubé, L., \& Renaghan, L. M. (1999). Building Customer Loyalty: Guests' Perspectives on the Lodging Industry's Functional Best Practices (Part I). Cornell Hotel and Restaurant Administration Quarterly, 40, 78. http://dx.doi.org/10.1177/001088049904000512

Forgas, S., Moliner, M. A., Sa'nchez, J., \& Palau, R. (2010). Antecedents of airline passenger loyalty: Low-cost versus traditional airlines. Journal of Air Transport Management, 16, 229-233. http://dx.doi.org/10.1016/j.jairtraman.2010.01.001

Gilbert, D., \& Wong, R. K. C. (2003). Passenger expectations and airline services: a Hong Kong based study. Tourism Management, 24, 519-532. http://dx.doi.org/10.1016/S0261-5177(03)00002-5

Hair, J. F., Black, W. C., Babin, B. J., \& Anderson, R. E. (2010). Multivariate Data Analysis (7th ed.). Upper Saddle River, NJ: Prentice-Hall.

Heal, F. (1990). Hospitality in Early Modern England. Oxford: Oxford University Press. http://dx.doi.org/10.1093/acprof:oso/9780198217633.001.0001

Hepple, J., Kipps, M., \& Thomson, J. (1990). The concept of hospitality and an evaluation of its applicability to the experience of hospital patients. International Journal of Hospitality Management, 9(4), 305-318. http://dx.doi.org/10.1016/0278-4319(90)90038-Y

Heung, V. C. S., Wong, M. Y., \& Qu, H. (2000). Airport-restaurant Service Quality in Hong Kong: An Application of SERVQUAL. Cornell Hotel and Restaurant Administration Quarterly, 41, 86. http://dx.doi.org/10.1177/001088040004100320

Hyun, S. S., Kim, W. S., \& Lee, M. J. (2011). The impact of advertising on patrons' emotional responses, perceived value, and behavioural intentions in the chain restaurant industry: The moderating role of advertising-induced arousal. International Journal of Hospitality Management. http://dx.doi.org/10.1016/j.ijhm.2010.10.008

Jones, P. (2004). Finding the hospitality industry? Or finding Hospitality school of thought? Journal of Hospitality, Leisure, sport \& tourism education, 3(1). http://dx.doi.org/10.1016/j.ijhm.2010.10.008

Kim, W. G., \& Moon, Y. J. (2009). Customers' cognitive, emotional, and actionable response to the servicescape: A test of the moderating effect of the restaurant type. International Journal of Hospitality Management, 28 , 144-156. http://dx.doi.org/10.1016/j.jhm.2008.06.010

Lashley, C. (2000). In search of hospitality: towards a theoretical framework. Hospitality Management, 19, 3-15. 
Lashley, C. (2008). Studying Hospitality: Insights from Social Sciences. Scandinavian Journal of Hospitality and Tourism, 8(1), 69-84. http://dx.doi.org/10.1080/15022250701880745

Liu, Y., \& Jang, S. C. (2009). The effects of dining atmospherics: An extended Mehrabian-Russell model. $\begin{array}{lllll}\text { International Journal of Hospitality } & \text { Management, } & \text { 28, }\end{array}$ http://dx.doi.org/10.1080/15022250701880745

Meng, J. G., \& Elliott, K. M. (2008). Predictors of relationship quality for luxury restaurants. Journal of Retailing and Consumer Services, 15, 509-515. http://dx.doi.org/10.1016/j.jretconser.2008.02.002

Mohsin, A., \& Lockyer, T. (2010). Customer perceptions of service quality in luxury hotels in New Delhi, India: an exploratory study. International Journal of Contemporary Hospitality Management, 22(2), 160-173. http://dx.doi.org/10.1108/09596111011018160

Morrison, A., \& O’Gorman, K. (2008). Hospitality studies and hospitality management: A symbiotic relationship. International Journal of Hospitality Management, 27, 214-22. http://dx.doi.org/10.1016/j.ijhm.2007.07.028

O'Connell, J. F., \& Williams. G. (2005). Passengers' perceptions of low cost airlines andfull service carriers: A case study involving Ryanair, Aer Lingus, Air Asia andMalaysia Airlines. Journal of Air Transport Management, 11, 259-272. http://dx.doi.org/10.1108/09596110510591954

O'Connor, D. (2005). Towards a new interpretation of .hospitality. International Journal of Contemporary Hospitality Management, 17(3), 267-271. http://dx.doi.org/10.1108/09596110510591954

Pakdil, F., \& Aydın, O. (2007). Expectations and perceptions in airline services: An analysis using weighted SERVQUAL scores. Journal of Air Transport Management, 13, 229-237. http://dx.doi.org/10.1016/j.jairtraman.2007.04.001

Sekaran, U., \& Bougie, R. (2010). Research methods for business: a skill building approach. UK: Wiley.

Talbott, B. M. (2006). The power of personal Service: why it matters, what makes it possible, how It creates competitive advantage. CHR Industry Perspectives, 1.

Usakli, A., \& Baloglu, S. (2011). Brand personality of tourist destinations: An application of self-congruity theory. Tourism Management, 32, 114-127. http://dx.doi.org/10.1016/j.tourman.2010.06.006

Wilkins, H., Merrilees, B., \& Herington, C. (2007). Towards an understanding of total service quality in hotels. Hospitality Management, 26, 840-853. http://dx.doi.org/10.1016/j.ijhm.2006.07.006

Wu, C. H., \& Liang, R. (2009). Effect of experiential value on customer satisfaction with service encounters in luxury-hotel restaurants. International Journal of Hospitality Management, 28, 586-593. http://dx.doi.org/10.1016/j.ijhm.2006.07.006

Yuksel, E., \& Riley, M. (2003). An investigation of self concept: actual and ideal self-congruence compared in the context of service evaluation. Journal of Retailing and Consumer Services, 10, 201-214. http://dx.doi.org/10.1016/S0969-6989(02)00008-5 